\title{
抗癌剤による薬剤性肺障害
}

酒井文和 $1 \cdot$ 長谷川瑞江 1

要旨——薬剤性肺障害は信頼に足る臨床検査法がなく, また画像診断所見も非特異的であることから, その診断には 臨床所見, 検査所見, 画像所見を総合して判断しなければならない. またその診断の確度も臨床診断レべルにとどまる ことが多い. 画像所見で DAD 類似型パターンを示す症例の予後は不良である. 既存の慢性間質性肺炎を中心とする肺 の破壊性病変の存在は, 薬剤性肺障害発症のリスク因子でもあり, 肺障害発症時の予後不良因子でもある. 薬剂性肺障 害診療における画像診断の役割は, 投与前のリスク評価としての慢性間質性肺炎の有無とその程度の評価, 発症時の画 像パターンによる予後や重症度の推定, 鑑別診断の一助, 経過観察や合併症発症の有無などにある. (肺癌. 2008;48: 721-726)

索引用語 一一薬剤性肺障害, 抗癌剤, 画像パターン, びまん性肺胞領域障害

\section{Imaging Evaluation of Drug-induced Lung Injury by Anticancer Drugs}

\author{
Fumikazu Sakai ${ }^{1}$; Mizue Hasegawa
}

\begin{abstract}
There are no reliable and safe laboratory tests to establish the diagnosis of drug-induced lung injury, and the imaging findings of drug-induced lung injury are nonspecific. It is mandatory to integrate clinical, laboratory, and imaging findings for a correct diagnosis of drug-induced lung injury. The reliablity of the diagnosis remains relatively low and clinical level. A diffuse alveolar damage pattern on images indicates an unfavourable prognosis. Preexisting destructive lung diseases such as chronic interstitial pneumonia is one of the predisposing factors of mortality and the morbidity of drug-induced lung injury. The roles of imaging in the management of patients with drug-induced lung injury include the detection of preexisting interstitial pneumonia, estimation of severity, and prognosis of druginduced lung injury, aid in differential diagnosis, determination of methods of follow-up and ways of detecting complications. (JJLC. 2008;48:721-726)
\end{abstract}

KEY WORDS — Drug-induced lung injury, Anticancer drugs, Imaging pattern, Diffuse alveolar damage

\section{1. はじめに}

Gefitinib などの最近の新しい抗癌剤では，高率に，ま た重篤な肺障害の発生が報告されており，一種の社会問 題にもなっている. 1-8 薬剤性肺障害は確実な診断法がな いことから，その診断には，臨床症状，検査所見，画像 診断所見などを総合して判断することが重要である. $9-12$
この稿では, 最近の抗癌剤を中心とする薬剤性肺障害の 画像診断, 鑑別診断とその問題点について概説したい.

\section{2. 抗癌剤による薬剤性肺障害の画像診断}

（1）薬剤性肺障害の画像所見

抗癌剤の薬剤性肺障害の画像は, 一般のその他の薬剤 性肺障害の画像と異なる点はなく, 非区域性の斑状ない

Reprints: Fumikazu Sakai, Department of Diagnostic Radiology, Saitama International Medical Center, Saitama Medical University, 1397-1 Yamane, Hidaka-shi, Saitama 350-1298, Japan(e-mail: fmksakai@saitama-med.ac.jp).

(C) 2008 The Japan Lung Cancer Society
1埼玉医科大学国際医療センター放射線科.

別刷請求先 : 酒井文和, 埼玉医科大学国際医療センター放射線 科，７350-1298＼cjkstart埼玉県日高市山根1397-1 (e-mail: fmksakai@ saitama-med.ac.jp).

1Department of Diagnostic Radiology, Saitama International Medical Center, Saitama Medical University, Japan. 

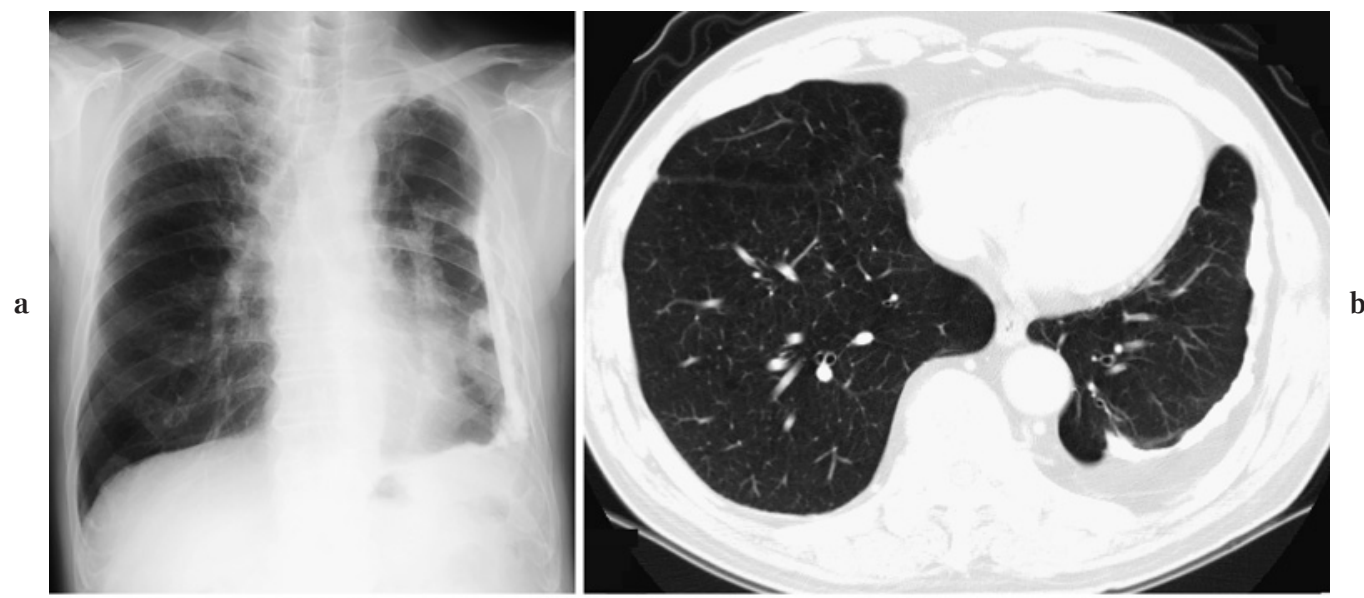

c
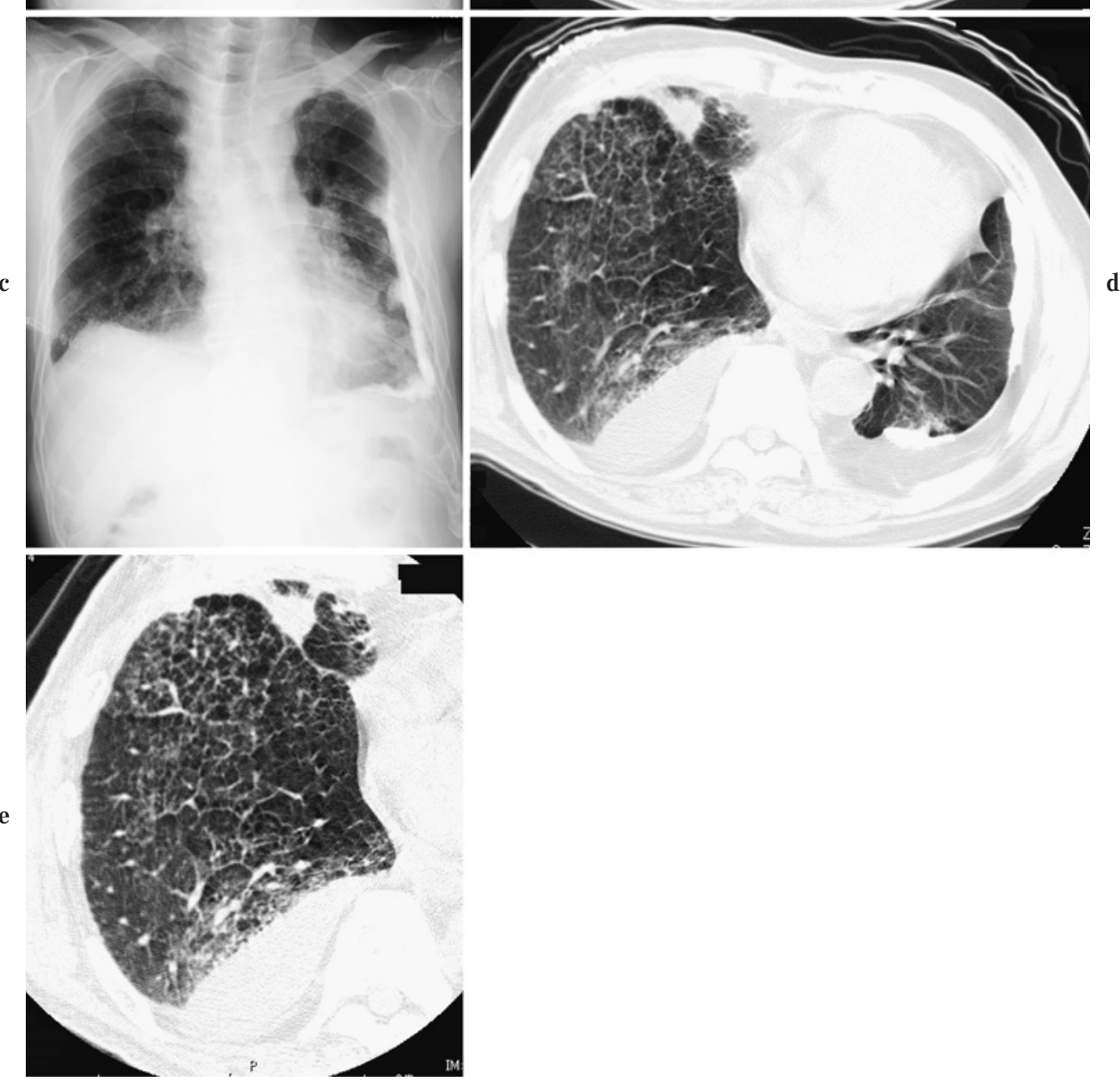

Figure 1. Drug-induced lung injury; less prominent abnormal opacity in disturbed side. a. CXR before the treatment of anticancer drug. CXR before the administration of anticancer drug shows lung cancer in the right pulmonary apex and thick calcified empyema in the left side. $\mathbf{b}$. CT before the treatment of anticancer drug. CT at the level of lower lung showed thick calcified empyema and increased extrapleural fat on the left side. c. CXR at the onset of drug-induced lung injury. CXR at the onset of drug-induced lung injury shows diffuse ground glass opacities in the bilateral lungs. d. CT at the onset of drug-induced lung injury. e. HRCT at the level of lower lung. CT and HRCT images show diffuse ground glass opacity with thickening of interlobular septa, predominant in the right. 


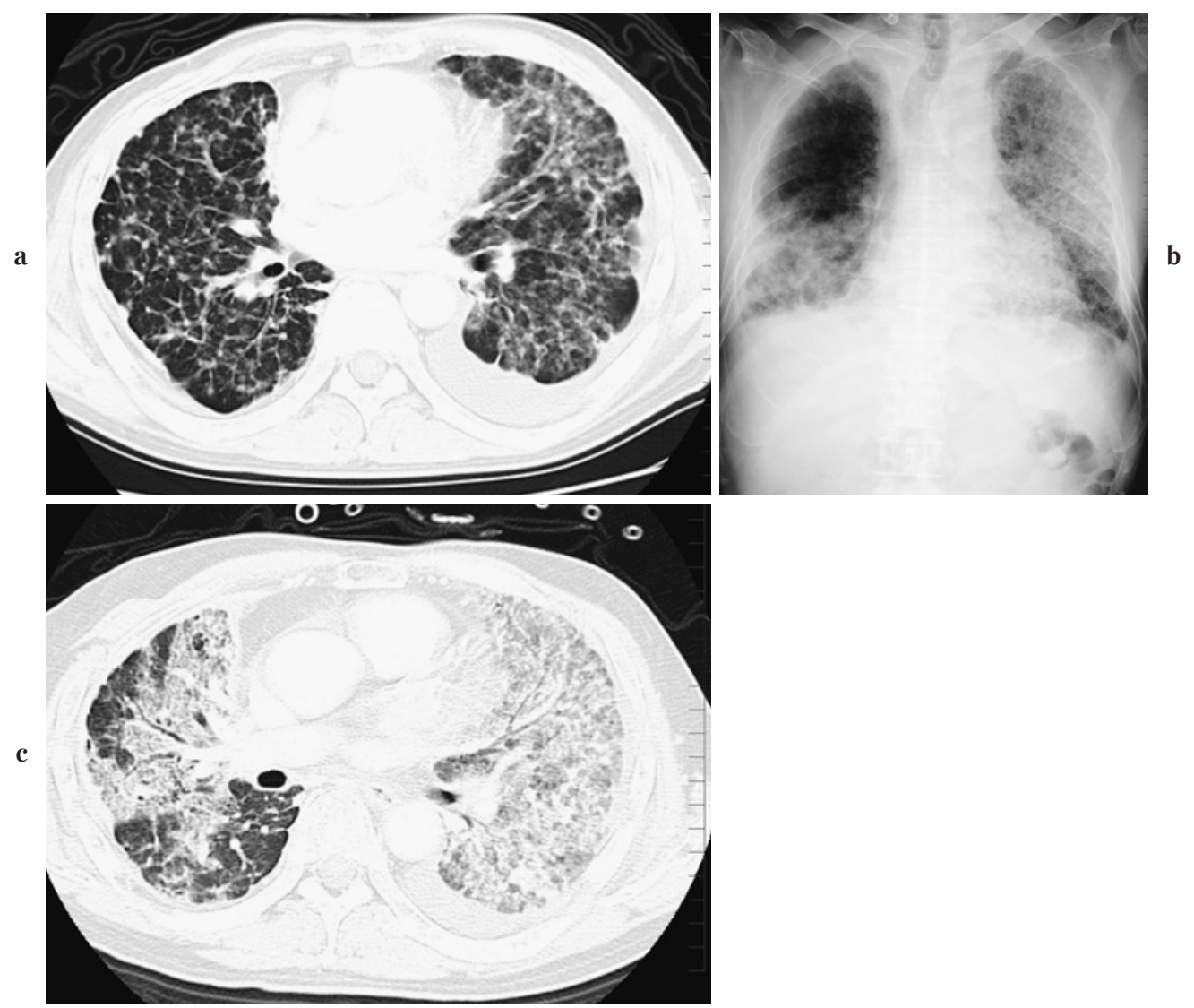

Figure 2. Gefitinib induced lung injury; diffuse alveolar damage like pattern. a. CT scan before the treatment of gefitinib. Multiple lung nodules and lymphangitic spread in a patient with lung cancer are evident in bilateral lungs. b. CXR at the onset of drug-induced lung injury. CXR at the onset of drug-induced lung injury shows diffuse bilateral ground glass opacity and right upper lung field is relatively spared. c. CT at the onset of drug-induced lung injury. Diffuse ground glass opacity; predominant in left side is identified in bilateral lungs. Traction bronchiolectasis is evident within ground glass opacity.

しびまん性のすりガラス院影や浸潤影である. $4,5,8,13-17$ す りガラス陰影内部には小葉内網状陰影が見られることが あり, 小葉間隔壁の肥厚を伴うこともまれではない. 13-16 多くの場合，陰影は両側性の非区域性陰影であるが，片 側に優位に見られることがありまれには片側性の院影を 示す．また一側肺に障害がある例では，健常側の肺に陰 影が優位に見られることが多い（Figure 1).

薬剤性肺障害の病理所見は, ほぼあらゆる既知の特発 性の肺疾患のパターンをとりうる。病理学上は特発性で いえばどのパターンに類似するかで分類され, 病理学的 所見から薬剂性肺障害に特徵的なものはなく, 病理所見 にもとずいて薬剤性肺障害と診断することはできない. また特発性の疾患と薬剤性肺障害でどのような相違があ るかの詳細な検討は行われていない.

画像所見は病理所見の反映であり, 従って画像所見も 極めて多彩である. 画像パターンによる分類も, 画像所
見がどの特発性の疾患のパターンに類似するかで分類さ れることが多い. 薬剤性肺障害にはいくつかの画像パ ターン分類が報告されている．画像パターン分類を使用 する際に注意すべきことは，あくまで画像パターンでの 類似性を求めるものであって, 多くの症例ではその病理 学的背景までも担保するものでないことである.すなわ ち薬剤性肺障害例では, 病理学的検索まで行われる症例 は比較的少なく，たとえ行われたとしても経気管支肺生 検であることが多い. 従って画像所見が真に病理学的裏 付けがあるかどうかの十分な検証は行われていない.

また leflunomide や gefitinibにおける肺障害例の retrospective な検討から既存の破壊性肺病変, とくに慢性 間質性肺炎が薬剤性肺障害発症時の予後不良因子である 可能性が示されていたが, 1-5 gefitinibの薬剤性肺障害の prospective な検討から, 既存の間質性肺炎は薬剤性肺障 害発症のリスク因子であることが明らかにされた. $6 こ$ 


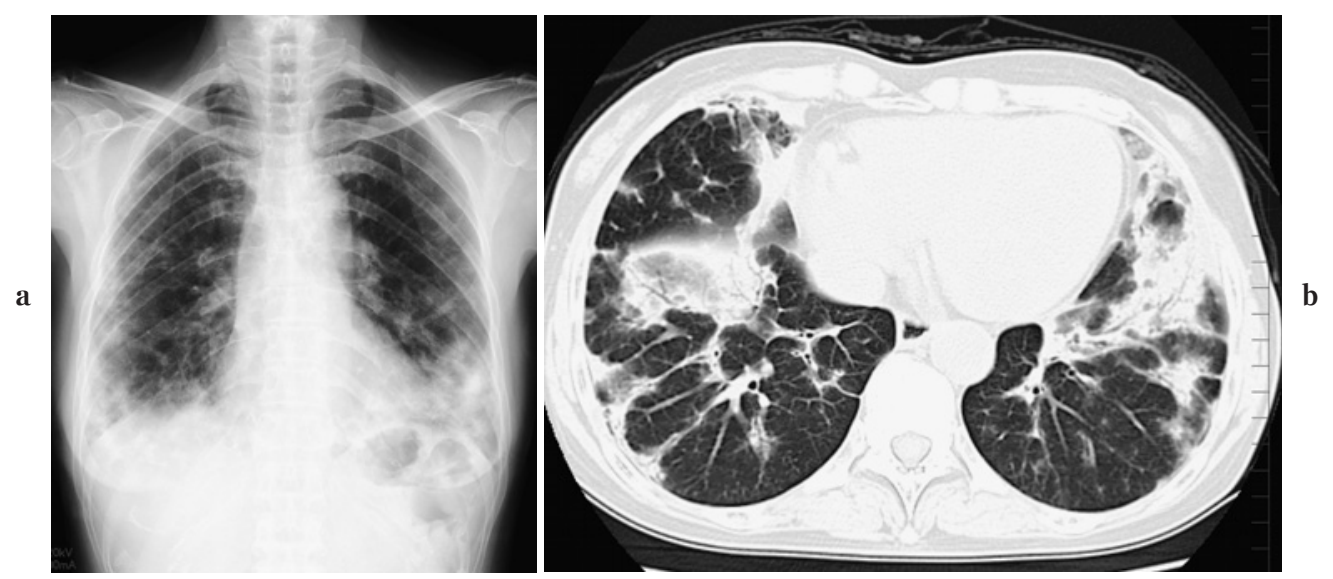

Figure 3. Sulfapyrazine induced lung injury in a patient with rheumatoid arthritis NSIP like pattern. a. CXR at the onset of drug-induced lung injury. CXR shows bilateral ground glass opacity with peribronchovascular distribution. b. CT at the onset of drug-induced lung injury. CT shows peribronchovascular consolidation with volume loss mimicking NSIP.

の検討の中では, 薬姷性肺障害発症のリスク因子として, 高齢, performance status の低下などがあげられた.

\section{（2）薬刘性肺障害の画像パターン}

薬剂性肺障害の画像パターンを特発性肺疾患の画像パ ターンとの類似性にもとずいて分類すれば, DAD, OP, NSIP, AEP, HP, その他のパターンなどに分けられ る. 18,19 びまん性肺胞領域障害 DAD（diffuse alveolar damage）類似パターンは, 特発性疾患でいえば AIP (acute interstitial pneumonia) に類似するパターンであ る20 (Figure 2). 画像上の特徵は, 広汎な浸潤影やすりガ ラス院影であり, その内部に, 線維化の出現を示す率引 性気管支拡張などの構造のゆがみ (structural distortion) の所見が見られることである．構造改変の所見が見られ ない病変の初期にはその診断が困難であるが, 陰影はか なり広範である. DAD 類似パターンは抗癌剤などの細 胞障害性薬荗のものが代表的である.

器質化肺炎 OP (organizing pneumonia) 類似パターン は, 肺野末梢の非区域性多発浸潤影をその所見とするも のである. $21-23$ 慢性好酸球性肺炎もこれに類似したパ ターンを示す。陰影は時に血管気管支束沿いの分布を示 す.また特発性器質化肺炎 (cryptogenic organizing pneumonia）で時に見られる reversed halo sign を示すことも ある。

急性好酸球性肺炎 AEP (acute eosinophilic pneumonia）類似パターンは, 主に末梢側の斑状のすりガラス陰 影や浸潤影で，小葉間隔壁の肥厚や気管支血管束の肥厚 などのいわゆる広義間質㓌影が高度な例をさす. 24,25

非特異性間質性肺炎 NSIP (nonspecific interstitial pneumonia）類似パターンは気管支血管束沿いに分布す
るすりガラス陰影を主体とするパターン. 26 構造改変を 示す所見を伴うことがある (Figure 3).

過敏性肺炎 HP（hypersensitivity pneumonia）類似パ ターンは, 広汎なすりガラス陰影が主体で, 構造改変を 示す所見はなく, 小葉内網状陰影を伴うことが多い. し ばしば汎小葉性分布あるいはこれが多数融合した多小葉 性分布を示す (Figure 4). また小粒状除影が混在するこ とがある. 病理学的背景には, リンパ球や形質球の肺胞 隔壁への浸潤と小さな肉芽腫の形成の, いわば肉芽腫性 間質性肺炎ともいうべきパターンであるが, 27,28 気道吸 入抗原に対する過敏性肺炎とは異なり小葉中心性分布は とらない. 抗腫瘍剤では, paclitaxelによるものが代表的 である。

これらの画像パターン分類は, 観察者間の一致率があ まりよくないこと, 病理学的背景の検証が十分に行われ ていないことなど限界があることは事実である。しかし $\mathrm{DAD}$ 類似型ではその生命予後が不良であり, 最も重要 な点は DAD 類似型か, それ以外のパターンか, にあるも のと考えられる。

\section{3. 薬剤性肺障害の鑑別診断とその問題点}

一般的には薬剤性肺障害の鑑別として重要な疾患は, 薬荗を投与する原疾患の肺病変あるいはその増悪と感染 症である。とくに肺癌においては, 高率に慢性間質性肺 炎を中心とする肺病変を伴い, このような症例では間質 性肺炎の増悪の可能性は常に考慮すべきであること, ま た抗癌剤による免疫抑制下では各種の感染症が発生しや すい点が重要である。これらの感染症の画像は薬剤性肺 障害の画像に極めて類似することがあり, 画像のみによ 
a

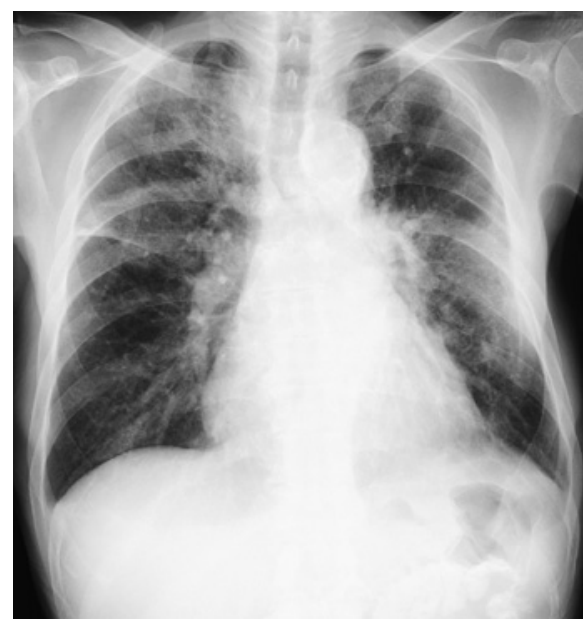

b

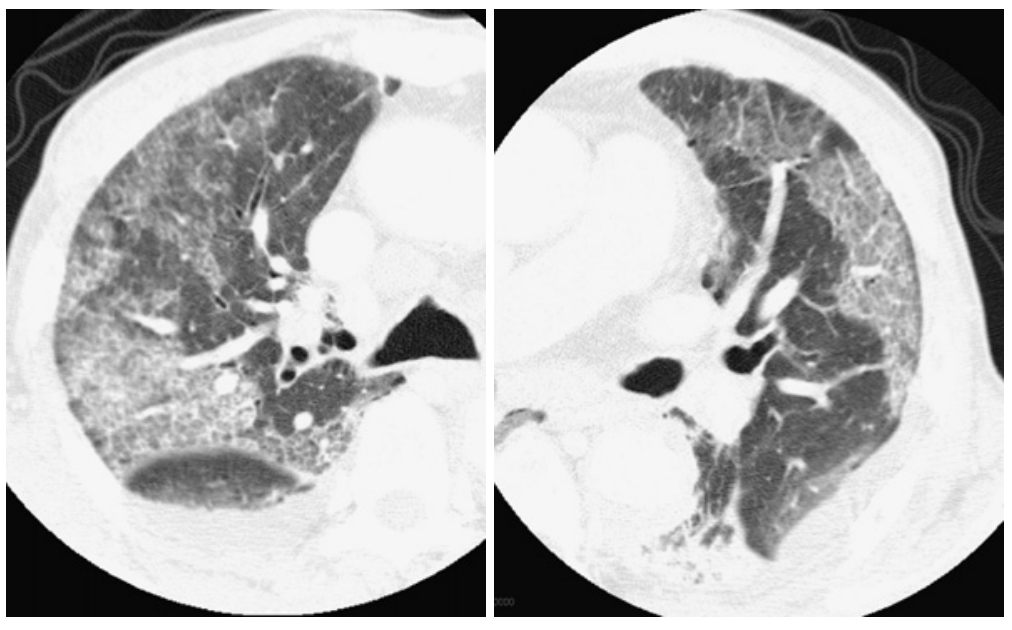

Figure 4. Docetaxel induced lung injury; HP-like pattern. a. CXR at the onset. CXR shows widespread ground glass opacity in bilateral lungs. b, c. HRCT at the onset of drug-induced lung injury. HRCT images show panlobular or multilobular ground glass opacity, predominantly in the subpleural regions, mimicking hypersensitivity pneumonitis. Intralobular reticular opacities were also evident.

る鑑別診断は困難である．鑑別のためには，症状や画像 所見と薬剂投与の時間的関係, 経過, 原疾患の病勢, リ ンパ球数などの免疫状態, 抗菌剤の予防投与の有無, 気 道分泌物の細菌学的検索, 各種血清学的マーカーなどを 総合して判断しなければならない.

\section{4. 薬剤性肺障害診療における画像診断の役割}

薬剤性肺障害診療における画像診断の役割は, 以下に あるものと思われる。すなわち（1）薬剤性肺障害発症の 早期診断と確認，（2）発症時の鑑別診断の一助，（3）既 存の間質性肺炎の評価, (4) 発症時の画像パターンによ る予後の推定，（5）治療効果の判定と経過観察などであ る.

\section{（1）薬剤性肺障害発症の早期診断と確認}

薬剤性肺障害の臨床症状は非特異的であり, 胸部異常 陰影の出現は, 肺障害発症の客観的所見として重要であ る.また淡いすりガラス陰影などは単純撮影よりは CT の方がより鋭敏にその存在を指摘しうるし，単純撮影で 片側性に見える陰影でも CT では両側性の院影として見 られることも少なくない.

\section{(2) 発症時の鑑別診断の一助}

前述のように薬剤性肺障害では特徵的な画像所見はな く，画像所見による鑑別診断には限界がある。実際の鑑 別診断上問題になるのは薬剤を投与するにいたった原疾 患の悪化, 悪性腫瘍においては, 癌性リンパ管症や腫瘍 の進展, 感染症である. 細菌性肺炎では OP 類似型の薬剤 性肺障害が鑑別診断の対象になる。また免疫不全患者で は, pneumocystis 肺炎や cytomegalovirus (CMV) 肺炎など
の広汎なすりガラス陰影をきたす感染症が薬剤性肺障害 の鑑別診断として極めて重要である.

\section{（3）既存の間質性肺炎の評価}

既存の間質性肺炎の存在は, 薬剤性肺障害発症のリス ク因子であり, また薬剤性肺障害発症時の予後不良因子 でもある. Gefitinib や leflunomide 8 は, 当初間質性肺炎 のある患者にも使用され重篤な肺障害が頻発したが, そ の後間質性肺炎のある患者に使用が控えられるように なってから重篤肺障害が激減した．また gefitinibとその 他の抗癌剤による薬剤性肺障害のリスク因子に関する前 向きの検討からも, 既存の間質性肺炎などの破壊性肺病 変の存在はリスクとなることが示されている. 6 実際の 臨床の場では, 画像診断の最も大きな役割は, この既存 間質性病変の有無や程度の評価にあると考えられる.

GefitinibのようにDAD 類似型肺障害の頻度が高い薬 剤では, 投与前の既存間質性肺炎の有無や程度を検索す ることは, 投与前のリスク評価の一環として重要と考え られる.

\section{（4）発症時の画像パターンによる予後の推定}

前述のようにDAD 類似型の画像を示す例では, 予後 が不良な傾向にある点は薬剤性肺障害発症後の生命予後 を推定する上で重要であると思われる. しかし, その他 の画像パターンを示す例からも少数であるが, 死亡例も でている点は注意が必要である.

\section{（5）治療効果の判定と経過観察}

治療効果の判定と経過観察は画像診断の主目的のひと つとして重要である。 


\section{5. まとめ}

薬剂性肺障害の画像所見，薬剂性肺障害診療における 画像診断の役割について概説した.

\section{REFERENCES}

1. Seto T, Yamamoto N. Interstitial lung diseases (ILD) induced by gefitinib in patients with advanced non-small cell lung cancer (NSCLC): Results of a West Japan Thoracic Oncology Group (WJTOG) epidemiological survey. Proc Am Soc Clin Oncol. 2004;23:629.

2. アストラゼネカ. iressa 錠 $250 \mathrm{mg}$ preospective 調査 (特 別調查）に関する結果と考察. 2004.

3. Inoue A, Saijo $\mathrm{Y}$, Maemondo M, Gomi K, Tokue $\mathrm{Y}$, Kimura Y, et al. Severe acute interstitial pneumonia and gefitinib. Lancet. 2003;361:137-139.

4. 酒井文和, 楠本昌彦, 上甲 剛. ゲフィチニブ (イレッ サ $^{\circledR}$ ）による肺障害：画像診断．日本胸部臨床．2003;62: 496-505.

5. 酒井文和, 上甲 剛, 楠本昌彦. Gefitinib による薬剤性肺 障害. 臨床放射線. 2004;49:1-8.

6. Kudoh S, Kato H, Nishiwaki Y, Fukuoka M, Nakata K, Ichinose $\mathrm{Y}$, et al. Interstitial lung disease in Japanese patients with lung cancer: a cohort and nested case-control study. Am J Respir Crit Care Med. 2008;177:1348-1357.

7. Miyakoshi S, Kami M, Yuji K, Matsumura T, Takatoku M, Sasaki M, et al. Severe pulmonary complications in Japanese patients after bortezomib treatment for refractory multiple myeloma. Blood. 2006;107:3492-3494.

8. Sakai F, Noma S, Kurihara Y, Yamada H, Azuma A, Kudoh S, et al. Leflunomide-related lung injury in patients with rheumatoid arthritis: imaging features. Mod Rheumatol. 2005;15:173-179.

9. Camus P. Drug induced infiltrative lung diseases. In: Schwarz MI, King TE Jr, eds. Interstitial lung disease. Hamilton: B.C. Decker; 2003:485-534.

10. Limper AH. Chemotherapy-induced lung disease. Clin Chest Med. 2004;25:53-64

11. 日本呼吸器学会薬剤性肺障害ガイドライン作成委員会 薬剂性肺障害の評価，治療についてのガイドライン。東 京：メディカルレビュー社；2005:39-42.

12. Rosenow EC 3rd, Limper AH. Drug-induced pulmonary disease. Semin Respir Infect. 1995;10:86-95.

13. 酒井文和. 画像診断からみた薬剤性肺障害. Medical Science Digest. 2005;31:174-177.

14. Akira M, Ishikawa H, Yamamoto S. Drug-induced pneumonitis: thin-section CT findings in 60 patients. Radiology. 2002;224:852-860

15. Padley SP, Adler B, Hansell DM, Müller NL. Highresolution computed tomography of drug-induced lung disease. Clin Radiol. 1992:46:232-236.

16. Rossi SE, Erasmus JJ, McAdams HP, Sporn TA, Goodman PC. Pulmonary drug toxicity: radiologic and pathologic manifestations. Radiographics. 2000;20:1245-1259.

17. Erasmus JJ, McAdams HP, Rossi SE. High-resolution CT of drug-induced lung disease. Radiol Clin North Am. 2002; 40:61-72.

18. Wittram C, Mark EJ, McLoud TC. CT-histologic correlation of the ATS/ERS 2002 classification of idiopathic interstitial pneumonias. Radiographics. 2003;23:1057-1071.

19. Johkoh T, Müller NL, Cartier Y, Kavanagh PV, Hartman TE, Akira M, et al. Idiopathic interstitial pneumonias: diagnostic accuracy of thin-section CT in 129 patients. $R a$ diology. 1999;211:555-560.

20. Johkoh T, Müller NL, Taniguchi H, Kondoh Y, Akira M, Ichikado $\mathrm{K}$, et al. Acute interstitial pneumonia: thinsection CT findings in 36 patients. Radiology. 1999;211: 859-863.

21. Lee KS, Kullnig P, Hartman TE, Müller NL. Cryptogenic organizing pneumonia: CT findings in 43 patients. AJR Am J Roentgenol. 1994;162:543-546.

22. Akira M, Yamamoto S, Sakatani M. Bronchiolitis obliterans organizing pneumonia manifesting as multiple large nodules or masses. AJR Am J Roentgenol. 1998;170:291-295.

23. Kim SJ, Lee KS, Ryu YH, Yoon YC, Choe KO, Kim TS, et al. Reversed halo sign on high-resolution CT of cryptogenic organizing pneumonia: diagnostic implications. $A J R$ Am J Roentgenal. 2003;180:1251-1254.

24. Johkoh T, Müller NL, Akira M, Ichikado K, Suga M, Ando M, et al. Eosinophilic lung diseases: diagnostic accuracy of thin-section CT in 111 patients. Radiology. 2000; 216:773-780.

25. Kim Y, Lee KS, Choi DC, Primack SL, Im JG. The spectrum of eosinophilic lung disease: radiologic findings. $J$ Comput Assist Tomogr. 1997;21:920-930.

26. Johkoh T, Müller NL, Colby TV, Ichikado K, Taniguchi $\mathrm{H}$, Kondoh $\mathrm{Y}$, et al. Nonspecific interstitial pneumonia: correlation between thin-section CT findings and pathologic subgroups in 55 patients. Radiology. 2002;225:199204.

27. Alarcón GS, Kremer JM, Macaluso M, Weinblatt ME, Cannon GW, Palmer WR, et al. Risk factors for methotrexate-induced lung injury in patients with rheumatoid arthritis. A multicenter, case-control study. Methotrexate-Lung Study Group. Ann Intern Med. 1997; 127:356-364.

28. Imokawa S, Colby TV, Leslie KO, Helmers RA. Methotrexate pneumonitis: review of the literature and histopathological findings in nine patients. Eur Respir J. 2000;15:373-381. 